\title{
THE IMPORTANCE OF EARLY RECOGNITION AND TIMELY TREATMENT OF DELIRIUM IN INTENSIVE CARE UNITS
}

\section{AUTHORS}

Stašević Karličić Ivana ${ }^{1}$, Stašević Milena ${ }^{1}$, Đorđević Jelena ${ }^{1}$, Grbić Igor ${ }^{1}$, Dukić Dejanović Slavica ${ }^{2}$, Janković Slobodan ${ }^{2}$

${ }^{1}$ Clinic for Psychiatric Disorders Dr “Laza Lazarevic”, Department of Emergency Psychiatry, Belgrade, Serbia

${ }^{2}$ Faculty of Medical Sciences, University of Kragujevac, Kragujevac, Serbia

\begin{tabular}{l} 
CORRESPONDENT \\
\hline IVANA STAŠEVIĆ KARLIČIĆ \\
Clinic for psychiatric disorders “Dr \\
Laza Lazarević”, Belgrade, Serbia \\
$\square$ ivanastasevic73@gmail.com
\end{tabular}

\section{ABSTRACT}

Delirium is connected to bad short-term (the increase in hospital mortality rate and hospital days) and long-term outcomes (disfunctionality, institutionalisation, cognitive damage and post hospital-release dementia). The objective of this study is to determine whether there are possible incompatibilities of treatment of delirium with the recommendations in the guides of good clinical practice from developed countries. The grounded method was used in the study. The so called principal sampling of 17 psychiatrists, anesthesiologists and registered nurses was conducted. Afterwards, the unstructured interviews with the selectees were conducted, transcribed and analyzed immediately through coding, category and concept detection. Having completed this, the theoretical sampling of new interview examinees was conducted. Their analysis enabled the concepts to be linked into a working theory and graphically displayed. The new sampling, the new interviews and their analysis were then continued interactively until the saturation of the working theory was achieved and the final version of the theory was formulated based on the findings reached through the interviews. Having completed the principal sampling and coding of the transcripts led the researches to the saturation of the theory through the separation of eight categories: A - Delirium as a sign of system infection, B - Therapy - Anaesthesiologists administer benzodiazepines, whereas psychiatrists administer antipsychotics, $\mathrm{C}$ - An inconspicuous onset of delirium is overlooked, D - Bleeding as the cause of delirium, E -Anticholinergics as a cause of delirium, F - Misunderstanding the nature of delirium by anaesthesiologists, $G$-Being aware that the patient is vitally endangered, and $\mathrm{H}$ - The nurses apply enhanced health care measures. Delirium is a syndrome which can be prevented in $30-40 \%$ of cases (50). An etiological treatment would help avoid complicating delirium's clinical picture and would very much prevent poor outcomes, such as institutionalisation, cognitive damage and delirious patients' high mortality rate.

Key words: delirium, diagnosis, treatment, prevention

\section{INTRODUCTION}

Delirium is an etiologically nonspecific organic cerebral syndrome with an acute onset and a fluctuating course, characterised by simultaneous disorders involving consciousness, attention, perception, thought, psychomotor behaviour, emotion and sleep cycle [1]. Depending on the patient's psychomotor activity, delirium can be hyperactive, hypoactive or mixed. During their hospitalization $11-25 \%$ of hospitalized elderly patients suffer a delirium attack, while $29-31 \%$ of them develop a case of delirium in the course of their hospitalization [2]. The rate of delirium cases in Intensive Care Units (ICUs) is significantly higher and reaches $77 \%$ with ventilated patients, with a $45-87 \%$ incidence $[3,4]$. Delirium is connected to bad short-term (the increase in hospital mortality rate and hospital days) and long-term outcomes (disfunctionality, institutionalisation, cognitive damage and post hospital-release dementia) $[6,7,8]$. The severity of delirium could be reduced through various intervention procedures such as a rational titration of sedation and anaesthesia [9], slight exposure to benzodiazepines [10-12], sleep promotion [13], early mobilisation and occupational therapy in ICUs [14], the use of antipsychotics as well as other supportive measures $[15,16]$.

The treatment of delirium is conducted in intensive care units because it requires constant monitoring due to the fact that the patients are vitally threatened. In developed countries, there are guides of good clinical practice with clear guidelines in terms of screening, diagnostics and treatment of delirium [17-19]. The key principle of these guides is a holistic approach to treatment of delirium conducted by a multidisciplinary team with various clinical skills (a registered nurse, a psychologist, an anaesthesiologist and/or a physician of another specialty, a psychiatrist), all of which are necessary due to this syndrome's complex nature.

In Serbia, there are neither approved guides for treatment of delirium in ICUs, nor protocol-defined multidisciplinary teams and procedures for prevention, diagnostics or treatment of this syndrome. 


\section{STUDY OBJECTIVE}

The objective of this study is to determine whether there are possible incompatibilities of treatment of delirium with the recommendations in the guides of good clinical practice from other countries and thus form a comprehensive explanation of the genesis of this incompatibility based on which corrective measures could be planned.

\section{MATHERIAL AND METHODS}

\section{GROUNDED THEORY}

This research was commenced on the assumption that there are certain incompatibilities in treatment of delirium with the recommendations of guides of good clinical practice in developed countries. Based on this assumption, the so called principal sampling of psychiatrists, anesthesiologists and registered nurses was conducted. Afterwards, the researcher conducted unstructured interviews with the selectees, had the interviews transcribed and analyzed immediately through coding, category and concept detection. Having completed the principal interviews, the theoretical sampling of new interview examinees was conducted. The analysis of the new series of interviews enabled the concepts to be linked into a working theory and graphically displayed. The new sampling, the new interviews and their analysis were then continued interactively until the saturation of the working theory was achieved and the final version of the theory was formulated based on the findings reached through the interviews. In accordance with the flow rate of the saturation of the theory, 17 examinees were interviewed.

\section{RESULTS}

Having completed the principal sampling and coding of the transcripts, the qualitative research of the possible existence of certain incompatibilities in the treatment of delirium with the recommendations of the guides of good clinical practice from developed countries led the researches to the saturation of the theory through the separation of eight categories. These are: Category A - Delirium as a sign of system infection, Category B - Therapy - Anaesthesiologists administer benzodiazepines, whereas psychiatrists administer antipsychotics, Category C - An inconspicuous onset of delirium is overlooked, Category D - Bleeding as the cause of delirium, Category E -Anticholinergics as a cause of delirium, Category $\mathrm{F}$ - Misunderstanding the nature of delirium by anaesthesiologists, Category $\mathrm{G}$-Being aware that the patient is vitally endangered, and Category $\mathrm{H}$ - The nurses apply enhanced health care measures (Picture 1).

The results of a qualitative analysis point to ICU doctors' key and majority standpoint when it comes to treating delirious patients. It is mostly accepted that delirium is a life-threatening state. However, there are also different views which state that the basic problem with delirium is its behavioural aspect consistent with the psychomotor type of delirium. Bleeding, system infection and the use of anticholinergics are seen as its leading causes.

An incomplete knowledge of delirium's etiopathogenesis and clinical picture often results in a simplified approach to the treatment of delirious patients. The patients suffering from a hypoactive type of delirium are a potentially problematic group, because this type is often overlooked, resulting in a lack of treatment.

Anaesthesiologists' and psychiatrists' pharmacotherapeutic approach differs in the choice of psychopharmacs. Anaesthesiologists administer benzodiazepines more often, while psychiatrists prescribe antipsychotics immediately. Not being completely familiar with their

Picture 1. Work theory concept

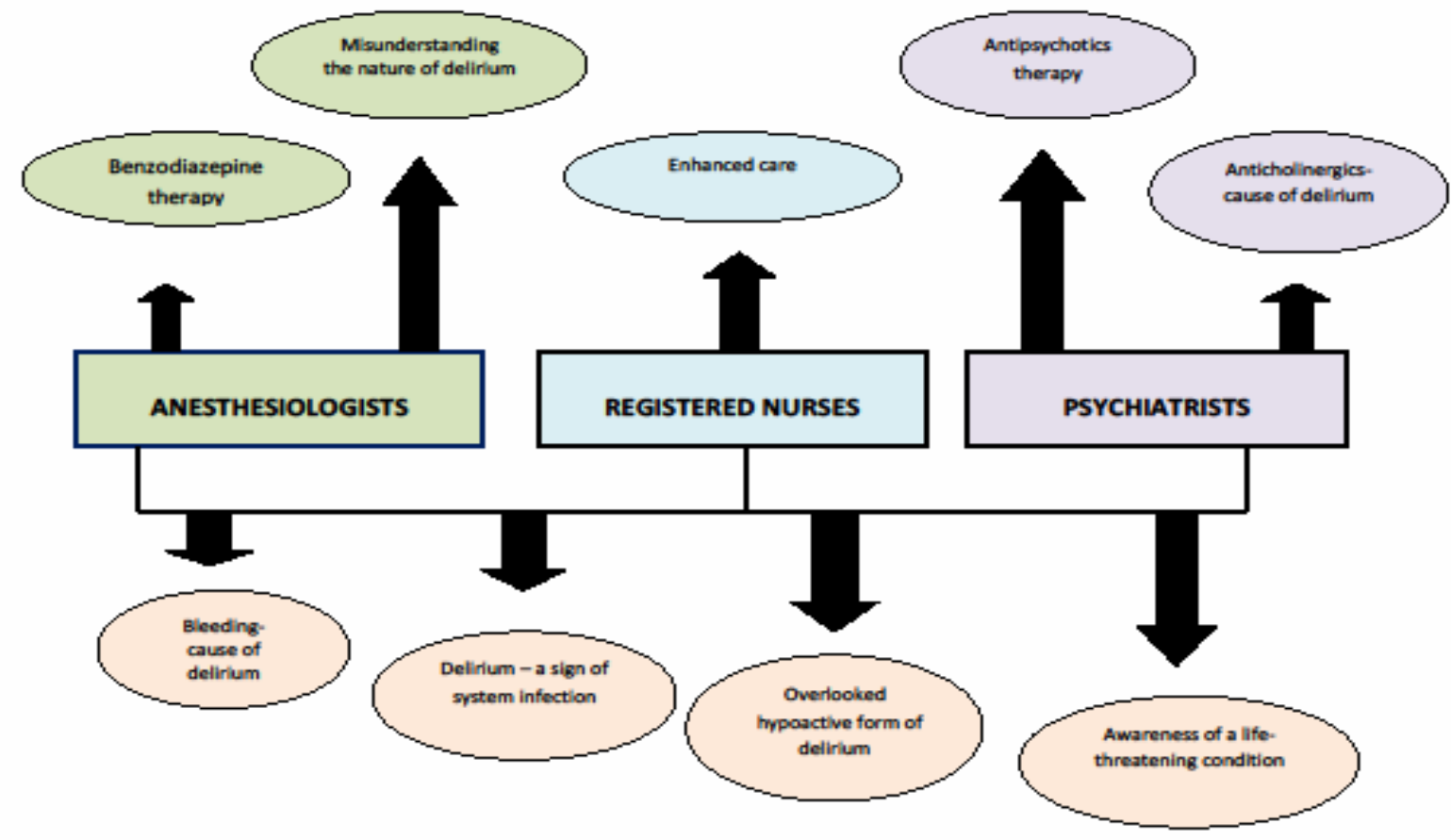


therapeutic effects, neither the former nor the latter are absolutely certain which pathogenic aspect these pharmacs are aimed at.

Registered nurses, approaching a delirious patient as a vitally endangered one, apply measures of enhanced health care.

\section{DISCUSSION}

The doctors' essential lack of knowledge as far as the pathogenesis and clinical picture are concerned, as well as the absence of a multidisciplinary approach to the treatment of delirium are the set of basic problems marked by this qualitative study. Despite the fact that many systems of organs in terms of damage or dysfunction are closely monitored in ICUs, by using pulse oximetry and gas analyses in lung damage monitoring, blood pressure and electrocardiography in heart dysfunction monitoring or diuresis and serum creatinine in renal dysfunction monitoring to give a few examples, the absence of instruments to monitor the most important organ of all - the brain - is very conspicuous. Monitoring the patients in terms of the development of delirium could perhaps be a good way of monitoring brain dysfunction, while modifications in treatment and care could help prevent this potentially catastrophic complication [20]. We should always bear in mind that delirium is a manifestation of damage to the brain, which in turn is the final product of a series of insults and injuries, occurring rather often i.e. in almost $80 \%$ of patients in critical condition hospitalised in ICUs [21]. In hospital services (Emergency Rooms, general wards in hospitals, post-operative and general ICUs) delirious patients suffer a higher mortality rate, a greater degree of cognitive damage, the number of hospital days is increased as well as the number of complications in hospital treatment [21]. Depending on its behavioural expression, three types of delirium can be discerned: hypoactive, hyperactive and mixed $[21,22]$. Peterson and others [23] found hypoactive delirium in its full form in less than $5 \%$ of the number of patients monitored out of an entire cohort of 613 ventilated and non-ventilated ICU patients where the cases of delirium were monitored in over 20000 observations. Hyperactive delirium is characterised by anxiety, agitation, psychotic symptoms and very often by heteroaggressiveness. The decline of mental and physical activity coupled with attention disorders is the chief characteristic of hypoactive delirium. The mixed type presents us with a constant alteration between the hypo and hyperactive type of delirium. Hypoactive delirium or the so called "silent delirium" is often overlooked by both the doctors and nurses, because delirium is seen by the majority of clinical practitioners as the presence of agitation and hallucinations $[20,24,25]$. Hypoactive delirium is most of ten seen in older patients coupled with aspiration, pulmonary embolism, bedsore and other complications common for immobile patients. On the other hand, extremely agitated patients (hyperactive delirium) do not only suffer the risk of extubating themselves but also the risk of removing their central venous catheter or falling off of their beds which could lead to possibly fatal injuries (20). Therefore, such patients are often over-sedated or even coupled to a mechanical ventilator again, which is one of the risk factors for the onset of delirium, closing the vicious circle $[20,26]$.
It is thought that delirium is connected to a disbalance in synthesis, release and inactivation of neurotransmitters responsible for the control of cognitive functions, behaviour and mood $[27,28]$. There are three neurotransmitter systems included in the pathophysiology of delirium: dopamine, gamma-aminobutyric acid (GABA) and acetylcholine [29]. Given that the central concentrations of these neurotransmitters are sensitive to many organic and biochemical changes, there are a lot of factors which could lead to their disbalance [20]. Van Rompey and others [30] split the risk factors for the onset of delirium in two groups: predisposing (the patient's characteristics and chronic pathology) and precipitating (acute illnesses and environmental factors). Inoai [22,31] also split the risk factors into predisposing and precipitating. In his opinion, the predisposing factors are the patient's characteristics which are difficult to modify more than 65 years of age, male, demented, cognitive damage, prior history of delirium, depression, immobility, sensory impairments, dehydration, malnutrition, alcohol abuse, prior psychopharmacs treatment, especially anticholinergics and the accompanying medical condition [31]. The precipitating factors act as triggers for the onset of delirium, but some of them could be modified through the application of preventive measures. These factors are: administering sedatives, opioids, anticholinergics, polypragmasy, addiction to alcohol and/or medicaments, a primary neurological illness, a new illness (infection, hypoxia, shock and metabolic disorders), type of surgery (orthopaedic or cardio surgery), admission to ICU, mechanical fixation, catheterisation and other similar procedures, pain, emotional stress and prolonged sleep deprivation.

It is always important to keep in mind that delirium can be a manifestation of a life-threatening condition which demands prompt treatment, such as hypoxia, hypoglycaemia, metabolic disorders or shock. Having quickly recognised and differentiated between the aforementioned conditions, the delirious patient should be subjected to a pharmacological and etiological treatment $[17,20]$. Nevertheless, it should be remembered that many pharmacs whose aim is to couple delirium's clinical picture can also have a prodeliriogenic effect and should be administered cautiously, in the smallest of doses and the shortest possible period of time. Benzodiazepines, which are most often used for sedation in ICUs, are not recommended for the treatment of delirium because their use could lead to over-sedation, worsening of the patient's confusion and breathing depression $[17,20,32]$. However, it should not be forgotten that they are the drugs of choice when it comes to delirium tremens (as well as other withdrawal syndromes) and convulsions.

The preliminary results of prospective randomised sedation studies in post-operative cardio-surgical patients show that the patients treated with dexmedetomidine, compared to those treated with propofol or midozlam, suffer a significantly lower rate of delirium onset [32]. Dexmedetomidine is one of the most frequently applied intravenous pharmacs used for sedation in ICUs. It is a non-benzodiazepine, highly selective alpha 2 - adrenergic agonist which links itself to the transmembrane g protein alpha $2 a$, alpha $2 b$ and alpha $2 c$ of the peripheral, cerebral and spinal adrenoreceptors [33]. Unlike other sedatives dexmedetomidine, by acting on the alpha 2 receptors of locus coeruleus [34], causes an- 
algesia [35] without the risk of breathing depression $[36,37]$. These characteristics make dexmedetomidine a potential primary option in delirium and agitation management in ICUs. Pasim and others published a metaanalysis in 2013 [38] suggesting that the dexmedetomidine treatment shortens the duration of intubation and stay in ICUs considerably. Likewise, its side-effects (an increased incidence of bradycardia and an increased risk of hypotension) had no influence on the overall mortality rate. Similar findings were referred to in a metaanalysis by Lynn and others [39] analysing the safety and efficiency of dexmedetomidine with post-operative cardio-surgical patients. Numerous studies comparing dexmedetomidine to propofol $[40,41]$, midazolam $[40,42,43]$, and morphine [44] confirmed that dexmedetomidine reduces the risk of delirium, agitation and/or confusion in critical ICU patients. This medicine is not yet registered in Serbia.

Many guideline brochures [17-19] recommend haloperidol as a primary choice medicine. It is a butyrophenone substance, a first generation antipsychotic and still the most often used neuroleptic agent in delirium treatment [20]. It does not suppress the respiratory centre and it acts as a powerful dopamine antagonist by blocking D2 central receptors, which results in coupling the positive symptomatology (hallucinations, delusion etc.) and a variable sedation effect. The newer, atypical antipsychotics (e.g. risperidone, quetiapine and olanzapine) can also be useful $[18,19]$ and they represent the second line in delirium treatment, while their therapeutic effect rests on the fact that they are not only dopamine antagonists, but they also significantly affect the levels of other neurotransmitters, such as serotonin, acetylcholine and noradrenaline. Beside the pharmacological, the guidelines also recommend a nonpharmacological approach to delirium prevention and treatment. In a study involving 852 patients over 70 years of age [48] the strategies for primary prevention of delirium resulted in the reduction of the onset of delirium by as much as $40 \%$. The protocol is focused on the optimisation of risk factors through the following methods: a repeated reorientation of a patient by trained volunteers and registered nurses, a continued cognitive stimulation of the patient three times a day, promoting a hygienic sleep regime which contributes the normalisation of the patient's sleep cycle, early mobilisation and physiotherapy, a timely removal of the catheter and mechanical fixation, constantly encouraging the patients to use eyeglasses, contact lenses and hearing-aid and a constant correction of dehydration [17-19]. Including the family can also be of great help in reorientation and pacification of a deliri- ous patient. It is also necessary to educate the patient's family about the nature, clinical picture and recognition of delirium [17-19]. According to all the guidelines, the registered nurses, aside from caring for the patient medically, together with the doctors, should conduct a continuous, simultaneous monitoring of the levels of sedation and onset of delirium [20]. Registered nurses and the rest of the ICU team have a duty to apply validated, objective and reliable instruments in monitoring the two components of consciousness (the level of wakefulness and the content of consciousness) [20]. Using the recommended standardised and objective instruments contributes the reduction of the rate of over-sedation and promotes the reduction of the duration of mechanical ventilation. The sedation level measurement scales help the members of the multidisciplinary team communicate during the discussions about the treatment objectives and the patient's care. To this purpose, one of the most frequently used and recommended scales is RASS [20]. The recommended and the most frequently used instrument in the early detection of delirium is CAM-ICU [20] whose sensitivity and specificity is higher than $95 \%$. It was designed as a sickbed assessment instrument (for nurses or doctors). It is easy to use, requires but a minute to apply, with a minimum of previous training $[20,49]$.

Delirium is a syndrome which can be prevented in $30-40 \%$ of cases [50]. High mortality rates are often the result of this diagnosis being overlooked, which is especially the case with the hypoactive types of delirium. Anyway, the advice of the British authors [51] stating that any change in behaviour and mental status in both psychiatric patients and the ones who are not is to be considered delirium until proven otherwise. In relation to that, in both these patients and the ones who are clearly delirious, a comprehensive diagnostics in terms of revealing all the etiological factors is a necessity. An etiological treatment would help avoid complicating delirium's clinical picture and would very much prevent poor outcomes, such as institutionalisation, cognitive damage and delirious patients' high mortality rate. It would significantly reduce the number of hospital days, the patient's personal suffering, as well as the overall treatment expenses which are borne by the health fund. An estimate of these expenses has never been done in Serbia, but the data from the USA and 18 European countries could serve to illustrate the point: around 164 billion dollars a year for the USA [52] and over 182 billion dollars a year for those 18 European countries together $[53,54]$.

\section{REFERENCES}

1. World Health Organization (WHO). International Classification of Diseases 10th Revision (ICD X). New York 2010.

2. Vasilevskis EE, Han HJ, Hughes GC, Ely WE. Epidemiology and risk factors for delirium across hospital settings. Best Practice \& Research Clinical Anaesthesiology 2012; 26: 277-287.

3. Agarwal V, O’Neill PJ, Cotton BA, Pun BT, Haney S, Thompson J et al. Prevalence and risk factors for development of delirium in burn intensive care unit patients. J Burn Care Res 2010; 31(5:706-715)

4. Thomason JW, Shintani A, Peterson JF, Pun BT, Jackson JC, Ely EW. Intensive care unit delirium is an independent predictor of longer hospital stay: a prospective analysis of 261 non-ventilated patients. Crit Care 2005;9(4):R375-81. 
5. Salluh JIF, Wang H, Schneider EB, Nagaraja N, Yenokyan G, Damluji A et al. Outcome of delirium in critically ill patients: systematic review and meta-analysis. BMJ 2015;350:h2538.doi:10.1136/bmj.h2538

6. Ely EW, Shintani A, Truman B, Speroff T, Gordon SM, Harrell Jr FE, et al. Delirium as a predictor of mortality in mechanically ventilated patients in the intensive care unit. JAMA 2004;291(14):1753-62.

7. Lin SM, Liu CY, Wang CH, Lin HC, Huang CD, Huang PY, et al. The impact of delirium on the survival of mechanically ventialted patients. Crit Care Med 2004;32(11):2254-9

8. Pompei P, Foreman M, Rudberg MA, Inouye SK, Braund V, Cassel CK. Delirium in hospitalized older persons: outcomes and predictors. J Am Geriatr Soc 1994;42:809-15

9. Sieber FE, Zakriya KJ, Gottschalk A, Blute MR, Lee HB, Rosenberg PB et al. Sedation depth during spinal anesthesia and the development of postoperative delirium in elderly patients undergoing hip fracture repair. Mayo Clin Proc 2010;85:18-26.

10. Riker RR, Shehabi Y, Bokesch PM, Ceraso D, Wisemandle W, Koura F et al. Dexmedetomidine vs midazolam for sedation of critically ill patients: a randomized trial. JAMA 2009;301:489-99.

11. Pandharipande PP, Pun BT, Herr DL, Maze M, Girard TD, Miller RR et al. Effect of sedation with dexmedetomidine vs lorazepam on acute brain dysfunction in mechanically ventilated patients: the MENDS randomized controlled trial. JAMA 2007;298:2644-53.

12. Fraser GL, Devlin JW, Worby CP, Alhazzani W, Barr J, Dasta JF et al. Benzodiazepine versus nonbenzodiazepine-based sedation for mechanically ventilated critically ill adults: a systematic review and meta-analysis of randomized trials. Crit Care Med 2013;41(suppl 1):S30-8.

13. Kamdar BB, King LM, Collop NA, Sakamuri S, Colantuoni E, Neufeld KJ et al. The effect of a quality improvement intervention on perceived sleep quality and cognition in a medical ICU. Crit Care Med 2013;41:800-9.

14. Schweickert WD, Pohlman MC, Pohlman AS, Niggos C, Pawlik AJ, Esbrook CL et al. Early physical and ocupational therapy in mechanically ventilated, critically ill patients: a randomized controlled trial. Lancet 2009,373:1874-82

15. Inouye SK, Bogardus ST Jr, Carpentier PA, Leo-Summers L, Acampora D, Holford TR et al. A multicomponent intervention to prevent delirium in hospitalized older patients. N Engl J Med 1999;340:669-76.

16. Reston JT, Schoelles KM. In-facility delirium prevention programs as a patient safety strategy: a systematic review. Ann Intern Med 2013;158:375-80.

17. Work group on delirium. Practice Guideline for the Treatment of Patients With Delirium. American Psychiatric Association, Washington DC, 2010

18. Barr J, Fraser GL, Puntillo K, Ely EW, Gelinas C, Dasta JF, et al: Clinical Practice Guidelines for the Management of Pain, Agitation, and Delirium in Adult Patients in the Intensive Care Unit. The American College of Critical Care Medicine (ACCM); Society of Critical Care Medicine 2013. DOI: 10.1097/CCM.0b013e3182783b72

19. National Institute for Health and Care Excellence (2010). Delirium: diagnosis, prevention and management. NICE Clinical Guidlines 103. Available at www.nice.org.uk

20. Ely EW. Delirium in the Intensive Care Unit. In: Vincent JL (ed). Yearbook of Intensive Care and Emergency Medicine. Springer 2005; 721-734.

21. Vasilevskis EE, Han JH, Hughes CG, Ely EW. Epidemiology and risk factors for delirium across hospital settings. Best practise \& Research Clinical Anaesthesiology 2012; 26: 277-287.

22. Choi JG. Delirium in the intensive care unit. Korean J Anesthesiol 2013; 65(3): 195-202.

23. Peterson JF, Truman BL, Shintani A, Thomason JWW, Jackson JC, Ely EW. The prevalence of hypoactive, hyperactive, and mixed type delirium in medical ICU patients. J Am Geriatr Soc 2003; 51: S174

24. Francis J, Martin D, Kapoor WN. A prospective study of delirium in hospitalized elderly. JAMA 1990; 263:1097-1101.

25. Inouye SK. The dilemma of delirium: clinical and research controversies regarding diagnosis and evaluation of delirium in hospitalized elderly medical patients. Am J Med 1994; 97: 278-288.

26. Kollef MH, Levy NT, Ahrens T, Schaiff R, Premtice D, Sherman G. The use of continuous IV sedation is associated with prolongation of mechanical ventilation. Chest 1999; 114:541-548.

27. Justic M. Does „ICU psychosis“ really exist? Crit Care Nurse 2000; 20: 28-37.

28. Meagher DJ, Trzepacz PT. Motoric subtypes of delirium. Semin Clin Neuropsychiatry 2000; 5: 75-85.

29. Crippen D. Treatment of agitation and its comorbidities in the intensive care unit. In: Hilld NS, Levy M (ed). Ventilator Management Strategies for Critical Care. Marcel Dekker, Inc., New York 2001; 243-284.

30. Van Rompaey B, Elseviers MM, Schuurmans MJ, Shortridge-Baggett LM, Truien S, Bossaert L. Risk factor for delirium in intensive care patients: a prospective cohort study. Crit Care 2009; 13: R77.

31. Inouye SK. Delirium in older persons. N Engl J Med 2006; 354:1157-65.

32. Ely EW, Stephens RK, Jackson JC, Thomason JW, Truman B, Gordon S et al. Current opinions regarding the importance, diagnosis, and menagement of delirium in the intensive care unit: a survey of 912 health-care professionals. Crit Care Med 2004; 32: 106-112.

33. Paris A, Tonner PH. Dexmedetomidine in anaesthesia. Curr Opin Anaesthesiol 2005; 18: 412-418.

34. Huupponen E, Maksimow A, Lapinlampi P, Sarkela M, Saastamoinen A, Snapir A, et al. Electroencephalogram spindle activity during dexmedetomidine sedation and physiological sleep. Acta Aneaesthesiol Scand 2008; 52: 289-294. 
35. Guo TZ, Jiang JY, Buttermann AE, Maze M. Dexmedetomidine injection into the locus ceruleus produces antinociception. Anesthesiology 1996; 84: 873-881.

36. lirola T, Aantaa R, Laitio R, Kentala E, Lahtinen M, Wighton A, et al. Pharmacokinetics of prolonged infusion of high-dose dexmedetomidine in critically ill patients. Crit Care 2011; $15:$ R257.

37. Morsch R, Ferri M, Vasconcelos C, Neto AC, Akamine N, Machado FS. Dexmedetomidine as a sedative agent for more than 24 hours in actuely ill patients. Crit Care 2005; 9: P111.

38. Pasin L, Landoni G, Nardelli P, Belletti A, Di Prima AL, Taddeo D, et al. Dexmedetomidine reduces the risk of delirium, agitation and confusion in critically ill patients: A Meta-analysis of Randomised Controlled Trials. Journal of Cardiothoracic and Vascular Anesthesia 2014; 28(6): 1459-1466.

39. Lin YY, He B, Chen J, Wang ZN. Can dexmedetomidine be a safe and efficacious sedative agent in post-cardiac surgery patients? a meta-analysis. Critical Care 2012; 16: R169.

40. Jakob SM, Roukonen E, Grounds RM, Sarapohja T, Garratt C, Pocock SJ, et al. Dexmedetomidine for Long-Term Sedation I. Dexmedetomidine vs midazolam or propofol for sedation during prolonged mechanical ventilation: Two randomized controlled trials. JAMA 2012; 307: 1151-1160.

41. Corbett SM, Rebuck JA, Greene CM, Callas PW, Neale BW, Healey MA, et al. Dexmedetomidine does not improve patient satisfaction when compared with propofol during mechanical ventilation. Crit Care Med 2005; 33: 940-945.

42. Senoglu N, Oksuz H, Dogan Z, Yildiz H, Demirkiran H, Ekerbicer H. Sedation during non-invasive mechanical ventilation with dexmedetomidine or midazolam: A randomized, duble-blind, prospective study. Curr Ther Res Clin Exp 2010; 71: 141-153.

43. Van LJ, Huang QQ, Yue JX, Lin L, Li SH. Comparison of sedative effect of dexmedetomidine and midazolam for post-operative patinents undergoing mechanical ventilation in surgical intensive care unit. Zhongguo Wei Zhong Bing Ji Jiu Yi Xue 2011; 23: 543-546.

44. Shebabi Y, Grant P, Wolfenden H, Hammond N, Bass F, Campbell M, et al. Prevalence of delirium with dexmedetomidine compared with morphine based therapy after cardiac surgery: A randomized controlled trial (DEXmedetomidine COmpared to Morphine - DEXCOM Study). Anesthesiology 2009; 111: 1075-1084.

45. Shebabi Y, Bellomo R, Reade MC, Bailey M, Bass F, Howe B, et al. Sedation Practice in Intensive Care Evaluation Study I, Australian, New Zealand Intensive Care Society Clinical Trials G. Early goal-directed sedation versus standard sedation in mechanically ventilated critically ill patients: A pilot study. Crit Care Med 2013; 41: 1983-1991.

46. Roukonen E, Parviainen I, Jakob SM, Nunes S, Kaukonen M, Shepherd ST, et al. Dexmedetomidine for Continuous Sedation I. Dexmedetomidine versus propofol/midazolam for long-term sedation during mechanical ventilation. Intensive Care Med 2009; 35: $282-290$.

47. Martin E, Ramsay G, Mantz J, Sum-Ping ST. The role of the alpha2-adrenoceptor agonist dexmedetomidine in postsurgical sedation in the intensive care unit. J Intensive Care Med 2003; 18: 29-41.

48. Inouye SK, Bogardus ST Jr, Carpentier PA, Leo-Summers L, Acampora D, Holford TR et al. A multicomponent intervention to prevent delirium in hospitalized older patients. N Engl J Med 1999;340:669-76.

49. Ely EW, Inouye SK, Bernard GR, Gordon S, Francis J, May L, et al: Delirium in mechanically ventilated patients: Validity and reliability of the confusion assessment method for the intensive care unit (CAM-ICU). JAMA 2001; 286:2703-2710

50. Inouye SK, Westendorp GJR, Saczynski SJ. Delirium in elderly people. Published online 2013 http://dx.doi.org/10.1016/S01406736(13)60688-1

51. Gelder GM, Andreas CN, Lopez - Ibor Jr JJ, Geddes RJ. New Oxford Text book of Psychiatry. Oxford University press 2009 ; 1 : 325 $-333$.

52. Leslie DL, Marcantonio ER, Zhang Y, Leo-Summers L, Inouye KS. One-year health care costs associated with delirium in the elderly population. Arch Intern Med 2008; 168:27-32

53. WHO Regional Office for Europe. European hospital morbidity database. Copenhagen: World Health Organization, 2012.

54. Organization for Economic Co-operation and Development. OECD health data 2012. Paris: Organization for Economic Co-operation and Development, 2012

\section{SRPSKI}

\section{ZNAČAJ RANOG PREPOZNAVANJA I PRAVOVREMENOG LEČENJA DELIRIJUMA U JEDINICI INTENZIVNE NEGE}

Stašević Karličić Ivana ${ }^{1}$, Stašević Milena ${ }^{1}$, Đorđević Jelena ${ }^{1}$, Grbić Igor ${ }^{1}$, Đukić Dejanović Slavica ${ }^{2}$, Janković Slobodan ${ }^{2}$

${ }^{1}$ Klinika za psihijatrijske poremećaje Dr "Laza Lazarević", Beograd, Srbija

${ }^{2}$ Fakultet medicinskih nauka, Univerzitet u Kragujevcu, Kragujevac, Srbija

\section{SAŽETAK}

Delirijum je povezan sa lošim kratkoročnim (porast bolničkog mortaliteta i broja bolničkih dana) i dugoročnim ishodima (disfunkcionalnost, institucionalizacija, kognitivno oštećenje i demencija). Cilj ove studije je da se utvrdi da li postoje moguća neslaganja u le- 
čenju delirijuma sa preporukama vodiča dobre kliničke prakse u razvijenim zemljama. U studiji je korišćen metod utemeljene teorije. Takozvanim principijalnim uzorkovanjem u studiju je uključeno 17 psihijatara, anesteziologa i licenciranih sestara. Nakon toga, sa izabranim ispitanicima su sprovedeni nestruktuirani intervjui koju su transkribovani i odmah analizirani kroz kodiranje, otkrivanje kategorija i koncepata. Zatim je sprovedeno teoretsko uzorkovanje novih ispitanika. Analiza nove serije intervjua omogućila je povezivanje koncepata u radnu teoriju i njeno grafičko prikazivanje. Novo uzorkovanje, novi intervjui i njihova analiza su zatim nastavljeni interaktivno sve dok nije dobijena saturacija radne teorije $\mathrm{i}$ formulacija definitivne verzije teorije utemeljene na nalazima dobijenim kroz process intervjuisanja. Nakon principijalnog uzorkovanja i kodiranja transkripata došlo se do saturacije teorije kroz izdvajanje osam kategorija: A - Delirijum kao znak sistemske infekcije, B - Terapija - anesteziolozi primenjuju benzodiazepine, a psihijatri antipsihotike, C - Slabije izražen delirijum se previđa, D - Krvarenja kao uzrok delirijuma, E - Antiholinergici kao uzrok delirijuma, F - Nerazumevanje prirode delirijuma od strane anesteziologa, G - Svest o vitalnoj ugroženosti pacijenata i H - Sestre primenjuju mere pojačane nege. Delirijum je sindrom koji se može sprečiti u 30-40\% slučajeva. Etiološkim lečenjem bi se izbeglo komplikovanje slike delirijuma i dobrim delom bi se sprečili loši ishodi, kao što su institucionalizacija, kognitivno oštećenje i visoka smrtnost delirantnih pacijenata.

Ključne reči: delirijum, dijagnoza, lečenje, prevencija 